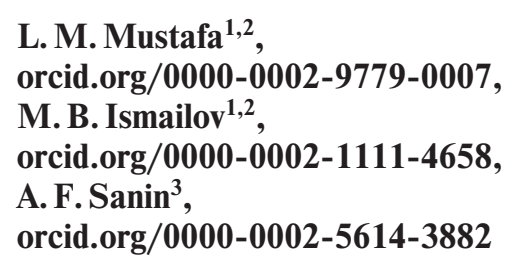

\section{STUDY ON THE EFFECT OF PLASTICIZERS AND THERMOPLASTICS ON THE STRENGTH AND TOUGHNESS OF EPOXY RESINS}

1 - "National Centre for Space Research and Technology" Joint Stock Company, Almaty, the Republic of Kazakhstan 2 - Satbayev University, Almaty, the Republic of Kazakhstan, e-mail: mustafa laura@mail.ru

3 - Oles Honchar National University, Dnipro, Ukraine, e-mail: afedsa60@gmail.com

Purpose. To increase the strength and toughness of epoxy resins of "cold hardening" and "hot hardening" by using modified plasticizers and thermoplastic polymers.

Methodology. Epoxy resins of "cold hardening" of ED-20 and "hot hardening" of Etal Inject-T, modified with three types of plasticizers and four types of thermoplastic polymers, were investigated. The toughness and compressive strength of unmodified and modified resins were determined with the help of the Charpy impact test at various modifier contents.

Findings. Among all studied plasticizers, tricresyl phosphate has the most significant effect on the strength and toughness of both types of resins. The best combination of strength and toughness of ED-20 resin is obtained with $5 \%$ tricresyl phosphate content, whereas its higher content reduces the strength of the material. For Etal Inject-T, high values of these properties are obtained with $15 \%$ tricresyl phosphate content, whereas adding a smaller amount of a modifier does not change the material strength. The modification with thermoplastic polymers has a less obvious effect on the properties of epoxy resins than the modification with plasticizers does. The most effective additives to ED-20 are high-temperature polycarbonate $(5 \%)$ and polysulfone (10 and $15 \%)$, the addition of which causes a simultaneous increase in both properties. A significant increase in the toughness of Etal Inject-T is observed by adding 5-15\% polycarbonate, but the strength of the resin hardly changes. The complex modification of resins with a mixture of plasticizer and thermoplastic leads to a decrease in the toughness and compressive strength of both types of resins.

Originality. When the polymer mixture hardens, plasticizer molecules dispersed into the environment of epoxy macromolecules weaken the rigid spatial crosslinking of macromolecules and make them more active. As a result, toughness increases; in certain cases so does resistance due to directed re-orientation of macromolecules under deformation. The change in mechanical properties of epoxy resin when modified with thermoplastics is defined by the bonding strength of the resin and dispersed particles of thermoplastic polymer as well as by the degree of hetero-phase of the produced mixture.

Practical value. The results of changing the mechanical properties of epoxy resin while being modified with plasticizers and thermoplastics can be used to produce impact-resistant composite materials for structural purposes, including those for aviation and space-rocket technology.

Keywords: epoxy resin, modifiers, plasticizers, thermoplastics, thermal treatment, toughness

Introduction. For the production of aerospace technology, light structural materials with high strength properties such as aluminum, magnesium, titanium alloys and polymer composite materials are used [1-3]. In this series, carbon fiber is several times larger than other materials in terms of specific strength and modulus of elasticity, but its weak point is the anomalously low toughness that does not exceed $50 \mathrm{~kJ} / \mathrm{m}^{2}$. For this reason, carbon fiber is still of limited use while constructing. The task of increasing the toughness of carbon fiber composite is relevant.

Literature review. The mechanical properties of carbon fiber composite depend both on the values of these characteristics of reinforcing carbon filler and resin, and the magnitude of adhesion of carbon filaments to epoxy resin (ER). Table 1 shows that thermosetting resin has low rates of elasticity and strength $[4,5]$.

At high static loads in carbon fiber, the matrix component deforms more strongly than carbon filaments, which leads to the rupture of the adhesive bond between the matrix and the reinforcement; at the end of the process, carbon filaments begin to tear. Fig. 1 shows the fracture surface of carbon fiber with a three-point bend. The bundles of free carbon filaments that are no longer connected to the thermoset matrix are visible.

Under shock loads on carbon, the fragile epoxy matrix first begins to break down; for this reason it determines the level of toughness of the carbon-fiber composite. Thus, the task of increasing the toughness of carbon fiber is largely achieved by increasing the toughness of epoxy resin with the help of modifiers.

Various plasticizers or thermoplastics are most often used [6] as modifiers of epoxy resins. Oleic acid, oligoxypropylene-

(C) Mustafa L. M., Ismailov M. B., Sanin A. F., 2020 glycol and $\delta$-chlorobutyl ester- $\beta$-chloropropionic acid were studied in the work [7] as the plasticizers for ED-20 epoxy resin on a polyethylene polyamine (PEPA) hardener. The best results were obtained when modifying the polymer by introducing $15 \%$ of the mass of oleic acid; in this case, the toughness increased from 3 to $17 \mathrm{~kJ} / \mathrm{m}^{2}$, the bending strength - from 17 to $105 \mathrm{MPa}$. In the work [8, 9], the effect of diethylene glycol diglycidyl ether (DEG-1), tricresylphosphate (TCP) and trichlorethylphosphate (TCEP) additives on the change in the properties of ED-20 epoxy resin was studied (Table 2).

Analyzing the data of Table 2, we can conclude that $30 \%$ content of diethylene glycol diglycidyl ether affects the properties of the composite matrix material most of all - the bending strength increases by 6.5 times, the toughness also increases, but not so noticeably - only by 1.5 times. We explain the observed result by the fact that DEG-1 is an active expanding material; it acts as a chemical modifier participating in the formation of the spatial structure while hardening together with ED-20. Increasing the content of tricresyl phosphate and trichloroethyl phosphate to $30 \%$ does not impact the material properties so much - the strength increases by 2 times, the toughness - by 1.3 times by adding TCP, and for TCEP it decreases due to the fact that these two compounds are plasticizers within the classical concept.

In some studies $[8,9]$, the authors research the effect of thermoplastics of polysulfone and polyethersulfone on the properties of ED-20 epoxy resin. It is shown that with an increase in the polysulfone content in epoxy resin to $20 \%$, the toughness of the composite increases from an initial value of $24.9 \mathrm{~J} / \mathrm{m}^{2}$ (determined on a Distant device) to $103 \mathrm{~J} / \mathrm{m}^{2}$, and the flexural strength - from 48.8 to $79.9 \mathrm{MPa}$. In the case of modification with polyethersulfone, the toughness of epoxy resin reaches a maximum of $102.3 \mathrm{~J} / \mathrm{m}^{2}$ at $20 \%$ modifier con- 
Table 1

Mechanical properties of the components of carbon fiber [4, 5]

\begin{tabular}{|l|l|c|c|}
\hline Material & \multicolumn{1}{|c|}{ Strength, MPa } & $\begin{array}{c}\text { Modulus of } \\
\text { elasticity, GPa }\end{array}$ & $\begin{array}{c}\text { Toughness, } \\
\mathrm{kJ} / \mathrm{m}^{2}\end{array}$ \\
\hline $\begin{array}{l}\text { Carbon } \\
\text { fiber }\end{array}$ & $\begin{array}{l}\text { 2500-6000 } \\
\text { stretching }\end{array}$ & $200-600$ & - \\
\hline $\begin{array}{l}\text { Epoxy } \\
\text { resin }\end{array}$ & $\begin{array}{l}100 \\
\text { stretching/compression }\end{array}$ & 10 & $3-40$ \\
\hline
\end{tabular}

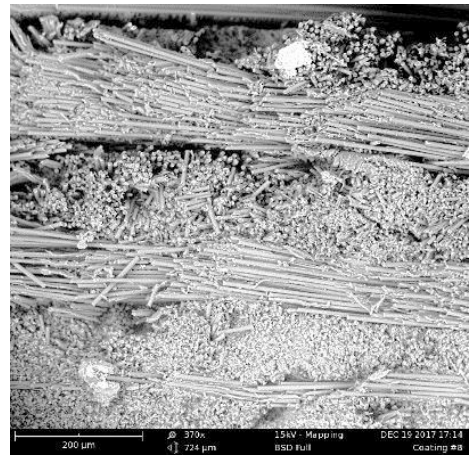

Fig. 1. Snapshot of the carbon composite material fracture surface

Table 2

Properties of composites based on ED-20 epoxy resin [7]

\begin{tabular}{|l|c|c|c|c|c|}
\hline & \multicolumn{5}{|c|}{ Content of modification, \% mass } \\
\cline { 2 - 6 } & - & $\begin{array}{c}\text { DEG-1 } \\
20\end{array}$ & $\begin{array}{c}\text { DEG-1 } \\
30\end{array}$ & $\begin{array}{c}\text { TCP } \\
30\end{array}$ & $\begin{array}{c}\text { TCEP } \\
30\end{array}$ \\
\hline Toughness, $\mathrm{kJ} / \mathrm{m}^{2}$ & 10 & 10 & 15 & 13 & 8 \\
\hline Bending strength, MPa & 17 & 86 & 110 & 34 & 34 \\
\hline
\end{tabular}

tent; the maximum bending strength of $94.0 \mathrm{MPa}$ is achieved with $5 \%$ modifier content, with a further increase in the modifier content, the strength is monotonously reduced to 75.7 MPa.

From the works $[6-8,10]$, it follows that the modification of epoxy resin with plasticizers and thermoplastics is promising both for increasing the toughness and strength of the composite. However, these works deal mainly with the widely used ED-20 "cold" hardening epoxy. Meanwhile, in the production technology of carbon fiber, epoxy resin "hot" hardening is of a great interest. One of the representatives of epoxy resin of this class is Etal-Inject-T ER [11], the hardening temperature of which is in the range from 150 to $180{ }^{\circ} \mathrm{C}$. At these temperatures, epoxy resin has a low viscosity and high flow; it moistens carbon fiber well and impregnates a carbon rebar, which improves the quality of the carbon fiber produced. At room temperatures, this epoxy resin with a hardener is in a liquid state, and it is very convenient for molding products.

There are no experimental data in the literature on the effect of modifiers on the toughness and strength of a thermoset Etal-Inject-T. The research in this direction would be interesting for the technology of production of high-impact carbon fiber.

The purpose of this work is to determine the effect of plasticizers and thermoplastics on the toughness and strength of epoxy resins of "hot" and "cold" hardening and compare their strength properties. For practical purposes, it is of interest to study the modifiers, the use of which will increase the toughness of epoxy resin while maintaining the level of strength or increase the strength while maintaining the level of toughness, as well as provide a balanced increase in the mechanical properties of epoxy.
Experimental part and research methodology. In the experiments, 2 epoxy resin types were used as a polymer binder:

- Etal Inject-T [11] with hardener at a mass ratio of components 100:49. Hardening was carried out according to the combined mode $150{ }^{\circ} \mathrm{C} 4$ hours + at $180{ }^{\circ} \mathrm{C} 1$ hour;

- ED-20 with hardener PEPA; the mass ratio of the components is 85:15; a hardening mode 48 hours at a room temperature.

To increase the toughness, the following modifying additives were used in the experiments:

- plasticizers such as tricresyl phosphate (TCP), trichloroethyl phosphate (TCEP) and glycidyl methacrylate (GDMA) [6] in a liquid state at a room temperature;

- thermoplastics such as polysulfone (PSF), polycarbonate (PC), polystyrene (PS) and high impact polystyrene (UPS). These polymers are in a solid state at a room temperature; when they are heated, they transform into a highly elastic or viscous flow state, and they have rather high temperatures of a viscous flow and decomposition. For example, for polysulfone, these temperatures are about 300 and $420^{\circ} \mathrm{C}$, respectively [10].

The modification of resin was carried out as follows: in epoxy resins (ED-20, "Etal Inject-T") modifiers were introduced in the amount of 5,10 and $15 \%$ of the total mass for each composition. Since the plasticizer is in a liquid state, its addition into epoxy resins is not difficult. Thermoplastics were added into the resin in the form of a dispersed material with a diameter of granules from 1 to $2.5 \mathrm{~mm}$, obtained by mechanical grinding without deep cooling. A modifier was added (total volume of the mixture was 1.51 ) in a cylindrical container with a diameter of $110 \mathrm{~mm}$ and a height of $180 \mathrm{~mm}$ with an epoxy oligomer (without hardener), then the components were mixed until a homogeneous mass was formed using a two-row mixer propeller stirrer at a speed of $150 \mathrm{rpm}$. The hardener was added after the formation of a homogeneous mass and it was mixed for 20 minutes. The finished mixture was poured into molds to obtain the samples of materials in the form of cylinders with a diameter of $15 \mathrm{~mm}$ and a height of $30 \mathrm{~mm}$ to determine the compressive strength and plates for impact testing with a length of $80 \mathrm{~mm}$, a width of $10 \mathrm{~mm}$ and a thickness of $4 \mathrm{~mm}$. Etal Inject-T resin samples were hardened in an electric furnace. Analyzing the surface of hardened epoxy resin, we found that the material structure was homogeneous, but heterogeneity of the structure was observed when modified with thermoplastics, and granular polymers acted like fillers. While polycarbonate was used, its particles were stored in ED-20 resin after cold hardening, but in Etal-Inject-T obtained by hot polymerization, there were no dispersed particles of the modifier, the material was completely homogeneous.

The toughness of unmodified and modified epoxy was determined by the Charpy impact test according to industry standard 4647-2015 [12] using a pendulum MK-15, the compressive strength - by using a universal testing machine MUP-200.

Results. Figs. 2 and 3 show the experimental data on the effect of TCP, GDMA, TCEP plasticizers on the toughness $\left(a_{i s}\right)$ and compressive strength $\left(\sigma_{\mathrm{cs}}\right)$ of the epoxy resin studied. Moreover, Table 3 shows the values of the plasticizer content at which the highest toughness of the modified epoxy resin is achieved when the level of unmodified strength is constant, the greatest compressive strength when the level of the toughness is constant, and a balanced increase in the toughness and strength of epoxy resin is observed.

It can be concluded that the investigated types of epoxy resin have close values of compressive strength; however, the toughness of Etal Inject-T is twice as high as the toughness of ED-20. The examined plasticizers have a significant effect on the toughness of resins causing an increase in their values up to $100 \%$, and, to a far less degree, contribute to the increase in the strength of ED-20 by $35 \%$ and Etal Inject-T by $15 \%$.

ED-20 resins containing tricresyl phosphate $5 \% \mathrm{TCP}$ and Etal Inject-T with $15 \%$ TCP have balanced mechanical properties. 


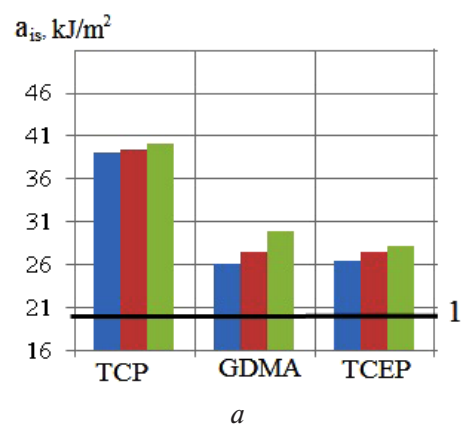

$\sigma_{c s,} \mathrm{MPa}$

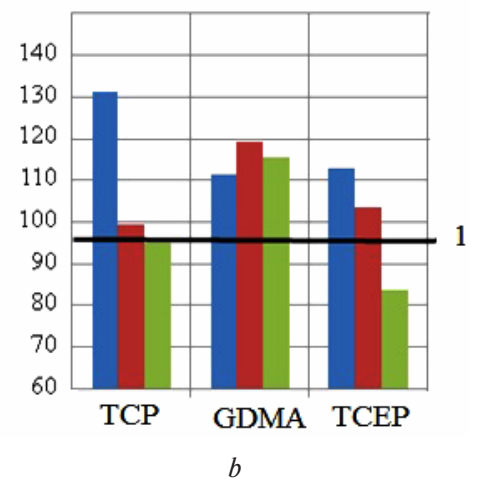

Fig. 2. The values of the toughness (a) and compressive strength (b) of ED-20 resin depending on the content of plasticizer ( 1 is for epoxy resin without a modifier):

$\square 5 \% \quad \square 10 \% \quad \square 15 \%$

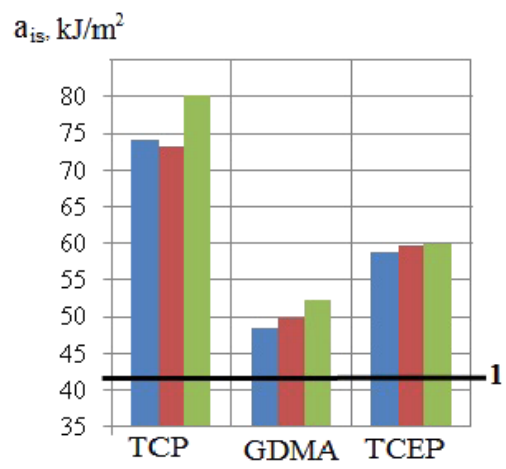

$a$

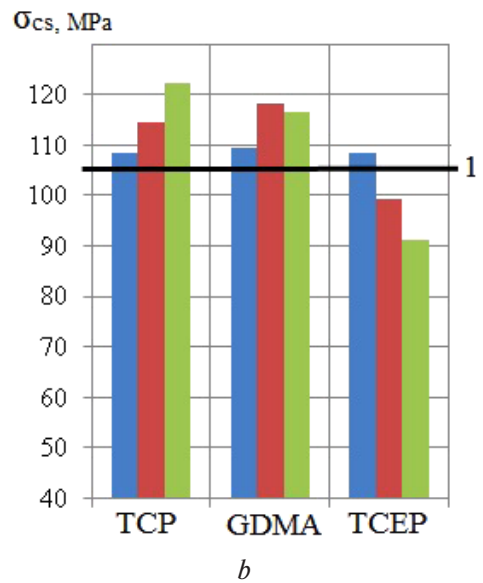

Fig. 3. The values of toughness (a) and compressive strength (b) of Etal Inject-T resin depending on the plasticizer content ( 1 is for epoxy resin without a modifier):

$\square 5 \% \quad 10 \% \quad \square 15 \%$
Table 3

Effect of plasticizers on the properties of epoxy resins

\begin{tabular}{|l|l|l|l|}
\hline \multicolumn{1}{|c|}{ ER } & \multicolumn{1}{|c|}{$\begin{array}{c}\text { ER with } \\
\text { maximum } \\
\text { toughness }\end{array}$} & $\begin{array}{c}\text { ER with } \\
\text { maximum } \\
\text { strength }\end{array}$ & \multicolumn{1}{c|}{$\begin{array}{c}\text { ER with } \\
\text { balanced } \\
\text { properties }\end{array}$} \\
\hline $\mathrm{ED}-20$ & $15 \% \mathrm{TCP}$ & $5 \% \mathrm{TCP}$ & $5 \% \mathrm{TCP}$ \\
$a_{n}=20.1 \mathrm{~kJ} / \mathrm{m}^{2}$ & $a_{n}=40.2 \mathrm{~kJ} / \mathrm{m}^{2}$ & $a_{n}=39 \mathrm{~kJ} / \mathrm{m}^{2}$ & $a_{n}=39 \mathrm{~kJ} / \mathrm{m}^{2}$ \\
$\sigma_{c s}=97 \mathrm{MPa}$ & $\sigma_{c s}=97 \mathrm{MPa}$ & $\sigma_{c s}=131 \mathrm{MPa}$ & $\sigma_{c s}=131 \mathrm{MPa}$ \\
\hline Etal Inject-T & $15 \% \mathrm{TCP}$ & $15 \% \mathrm{TCP}$ & $15 \% \mathrm{TCP}$ \\
$a_{n}=42.3 \mathrm{~kJ} / \mathrm{m}^{2}$ & $a_{n}=80.3 \mathrm{~kJ} / \mathrm{m}^{2}$ & $a_{n}=80.3 \mathrm{~kJ} / \mathrm{m}^{2}$ & $a_{n}=80.3 \mathrm{~kJ} / \mathrm{m}^{2}$ \\
$\sigma_{c s}=106 \mathrm{MPa}$ & $\sigma_{c s}=122 \mathrm{MPa}$ & $\sigma_{c s}=122 \mathrm{MPa}$ & $\sigma_{c s}=122 \mathrm{MPa}$ \\
\hline
\end{tabular}

Taking into account the observed insignificant increase in the toughness of the hardened ED with an increase in the number of liquid plasticizers, we can conclude that in this case there is intrastructural plasticization.

Plasticizers have high compatibility both with ED and the polymer chains of the spatial framework formed during its hardening. That is why the regulatory effect of plasticizers becomes apparent during the entire process of formation of the spatial network.

Adding plasticizer makes it possible to increase the toughness of ER and, in some cases, improve the strength due to the directed reorientation of macromolecules during deformation [8].

The second part of the experiments is devoted to the study of thermoplastics modifiers' impact on mechanical properties of epoxy resin. The experimental data are shown in Figs. 4 and 5 and Table 4.

All the thermoplastics considered increased both the toughness and the compressive strength of ED-20 resin. The best result concerning increasing the toughness (by $85 \%$ ) was obtained for ED-20 resin with a content of $15 \%$ thermoplastic
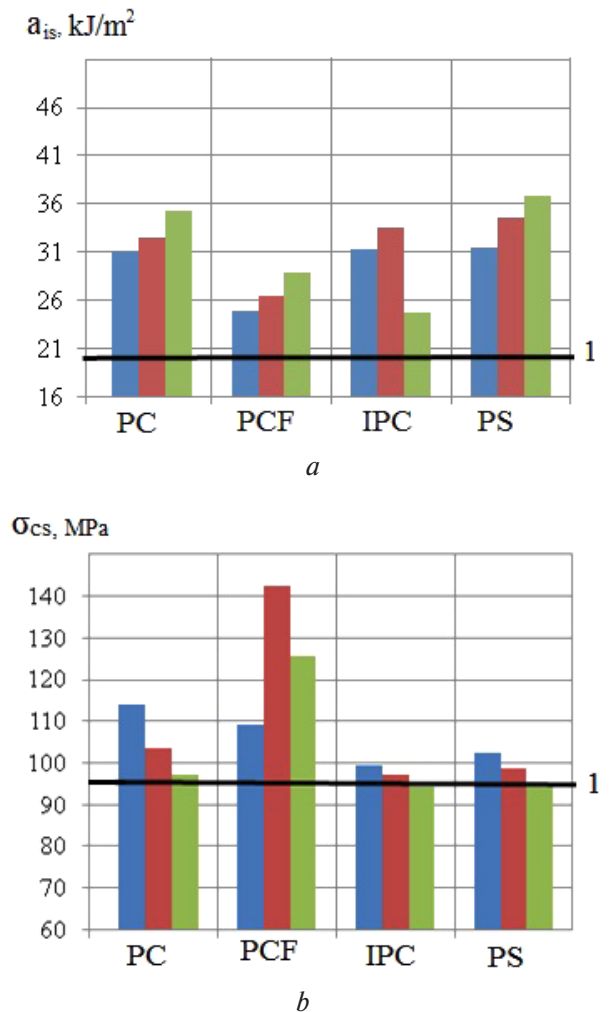

Fig. 4. The values of toughness and compressive strength of ED20 resin depending on the thermoplastic content (1 is for epoxy resin without a modifier):

ロ $5 \% \quad \square 10 \% \quad \square 15 \%$ 
$\mathrm{a}_{\mathrm{is}}, \mathrm{kJ} / \mathrm{m}^{2}$

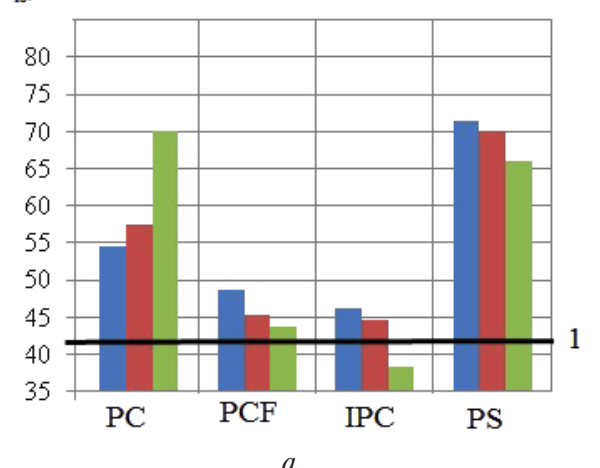

$\sigma_{\mathrm{cs},} \mathrm{MPa}$

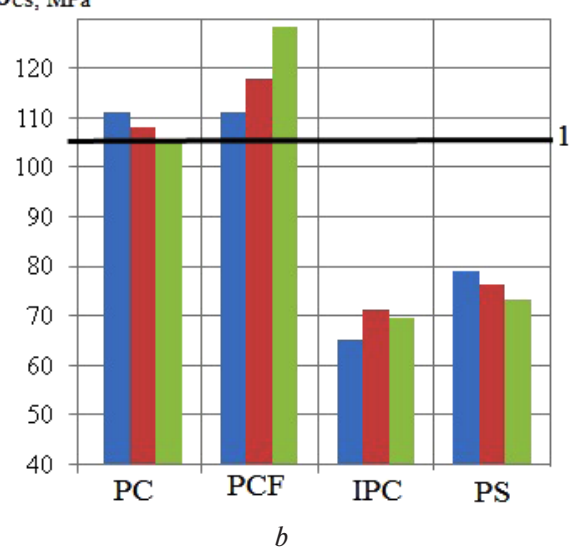

Fig. 5. The values of toughness and compressive strength of Etal Inject-T resin depending on the thermoplastic content ( 1 is for epoxy resin without a modifier):

$\square 5 \% \quad 10 \% \quad \square 15 \%$

PS, for Etal Inject-T was by $65 \%$, with a content of $5 \%$ PS. The maximum strength of ED-20 was increased by $47 \%$ with a content of $10 \%$ PCF, Etal Inject-T was by $21 \%$ with a content of $15 \%$ PCF. A modified resin with balanced mechanical properties was obtained with a polycarbonate content of 5 (ED-20) and $15 \%$ (Etal Inject-T).

Thermoplastic polymers make a heterophasic structure in ER, and this structure consists of resin macromolecules and thermoplastic microparticles, which form a spatial framework, so that, according to modern concepts, a reinforcing extended boundary layer is formed at the phase interface. While using such a matrix in the composite material, the level of mechanical properties (compared with the use of an unmodified matrix) and the nature of their change will depend on the amount of resin adhesion to the thermoplastic particles.

Due to the high elasticity of thermoplastics particles, their presence in the matrix of the hardened composite promotes to reduce the level of stresses arising in the material under mechanical loading.

The complex modification of Etal Inject-T resin with a mixture of plasticizer and thermoplastic for further improvement of the properties is of interest. The experimental results are shown in Table 5.

The analysis of the results presented in Table 5 allows us to conclude that the modification of epoxy resin with a mixture of tricresyl phosphate plasticizer and thermoplastic does not provide an additional increase in the mechanical properties comparing to using only a TCP modifier. On the contrary, there is a slight decrease in both toughness and compressive strength.

Thus, there is no additive effect on the properties of ER of plasticizer and thermoplast. We attribute this effect to the fact that the modes of the hardening action of plasticizers and ther-
Table 4

The effect of thermoplastics on the properties of epoxy resins

\begin{tabular}{|l|l|l|l|}
\hline Epoxy resin & $\begin{array}{c}\text { Epoxy resin } \\
\text { with } \\
\text { maximum } \\
\text { toughness }\end{array}$ & $\begin{array}{c}\text { Epoxy resin } \\
\text { with maximum } \\
\text { strength }\end{array}$ & $\begin{array}{c}\text { Epoxy resin } \\
\text { with balanced } \\
\text { properties }\end{array}$ \\
\hline $\mathrm{ED}-20$ & $15 \% \mathrm{PC}$ & $10 \% \mathrm{PCF}$ & $5 \% \mathrm{PC}$ \\
$a_{n}=20.1 \mathrm{~kJ} / \mathrm{m}^{2}$ & $a_{i s}=37 \mathrm{~kJ} / \mathrm{m}^{2}$ & $a_{i s}=26.5 \mathrm{~kJ} / \mathrm{m}^{2}$ & $a_{i s}=31.1 \mathrm{~kJ} / \mathrm{m}^{2}$ \\
$\sigma_{c s}=97 \mathrm{MPa}$ & $\sigma_{c s}=97 \mathrm{MPa}$ & $\sigma_{c s}=142.6 \mathrm{MPa}$ & $\sigma_{c s}=114 \mathrm{MPa}$ \\
\hline "Etal Inject-T" & $5 \% \mathrm{PC}$ & $15 \% \mathrm{PCF}$ & $15 \% \mathrm{PC}$ \\
$a_{n}=42.3 \mathrm{~kJ} / \mathrm{m}^{2}$ & $a_{i s}=70 \mathrm{~kJ} / \mathrm{m}^{2}$ & $a_{i s}=43.6 \mathrm{~kJ} / \mathrm{m}^{2}$ & $a_{i s}=70.1 \mathrm{~kJ} / \mathrm{m}^{2}$ \\
$\sigma_{c s}=106 \mathrm{MPa}$ & $\sigma_{c s}=106 \mathrm{MPa}$ & $\sigma_{c s}=128 \mathrm{MPa}$ & $\sigma_{c s}=107.4 \mathrm{MPa}$ \\
\hline
\end{tabular}

Table 5

Effect of a mixture of TKM and thermoplastic on the properties of hardened epoxy resin

\begin{tabular}{|c|c|c|c|}
\hline Epoxy resin & Modifier content & 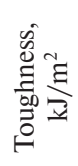 & 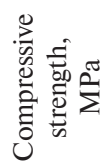 \\
\hline "Etal-Inject T" & - & 42.3 & 106 \\
\hline$-\ll-$ & $15 \%$ ТCP & 80.3 & 122 \\
\hline$-\ll-$ & $15 \% \mathrm{TCP}+5 \% \mathrm{PS}$ & 72 & 108.4 \\
\hline$-\ll-$ & $15 \% \mathrm{TCP}+5 \% \mathrm{PC}$ & 75.8 & 112.3 \\
\hline$-\ll-$ & $15 \% \mathrm{TCP}+5 \%$ IPS & 69 & 118.4 \\
\hline
\end{tabular}

moplastic dispersed fillers are significantly different, as suggested above. Therefore, the additive effect of factors causing a strengthening effect is not obtained if the additives are used separately. In contrast, the plasticizers being used together with thermoplastics, apparently, prevent the formation of a reinforcing interfacial layer "thermoplast-epoxy resin".

As a result, the dispersed particles do not show a strengthening effect, but, like internal defects, they are stress concentrators and can act as crack nucleus in the material.

Conclusions. The effect of plasticizers such as tricresylphosphate, trichloroethylphosphate, glycyldyl methacrylate and thermoplastic polymers such as polysulfone, polycarbonate, polystyrene, high impact polystyrene on the toughness and compressive strength of cold and hot hardening of ED-20 and Etal Inject-T epoxy resins was studied.

The most effective modifier to increase the toughness of ER was tricresyl phosphate with a content of $15 \%$. In this case, the toughness of ED-20 resin increased from 20 to $40.2 \mathrm{~kJ} / \mathrm{m}^{2}$ and Etal Inject-T resin rose from 42.3 up to $80.3 \mathrm{~kJ} / \mathrm{m}^{2}$ when their level of the compressive strength was constant.

Adding polysulfone thermoplastic had the greatest impact on the compressive strength. If its content was $10 \%$, the strength of ED-20 resin increased from 97 to $142.6 \mathrm{MPa}$, and the strength of Etal Inject-T rose from 106 to $128 \mathrm{MPa}$ with a content of $15 \%$, when the level of the toughness was constant.

The modification of epoxy resins with a mixture of plasticizers and thermoplastics is not effective due to the difference in the mode of the hardening action of plasticizers and thermoplastic dispersed fillers, as well as the prevention of plasticizers from the formation of a strengthening interfacial layer at the epoxy-thermoplastic interface.

Acknowledgements. The work was carried out as part of the RBP 008 BR05336383 target program of the Aerospace Committee of the Ministry of Defense and Aerospace Industry of the Republic of Kazakhstan "Development of a technology for the production of impact-resistant carbon plastics for defense and aerospace products" (2018-2020). 
References.

1. Levchenko, I., Bazaka, K., Belmonte, Th., Keidar, M., \& $\mathrm{Xu}$, Sh. (2018). Advanced Materials for Next-Generation Spacecraft. Advanced Materials, 30(50), 1-13. https://doi. org/10.1002/adma.201802201.

2. Ghidini, T. (2018). Materials for space exploration and settlement. Nature Materials, (17), 846-850. https://doi. org/10.1038/s41563-018-0184-4.

3. Gaidachuk, V.E., Kondratiev, A.V., \& Chesnokov, A. V. (2017). Changes in the thermal and dimensional stability of the structure of a polymer composite after carbonization. $\mathrm{Me}$ chanics of Composite Materials, 52(6), 799-806. https://doi. org/10.1007/s11029-017-9631-6.4.

4. Gunyaeva, A. G., Sidorina, A. I., Kurnosov, A. O., \& Klimenko, O.N. (2018). Polymeric composite materials of new generation on the basis of binder VSE-1212 and the filling agents alternative to ones of Porcher Ind. and Toho Tenax. Aviation Materials and Technologies, (3), 18-26. https://doi. org /10.18577/2071-9140-2018-0-3-18-26.

5. Dunn, B. D. (2016). Materials and Processes for Spacecraft and High Reliability Applications. Springer. ISBN10:3319233610, https://doi.org/10.1007/978-3-319-23362-8. 6. Mustafa, L. M., Yermakhanova, A. M., Ismailov, M. B., \& Sanin, A. F. (2019). Study of the effect of plasticizers and thermoplastics on the mechanical properties of epoxy and carbon fiber reinforced plastic (Review). Complex Use of Mineral Resources, (4), 48-56. https://doi.org/10.31643/2019/6445.37.

7. Mostovoy, A.S. (2015). Modification of epoxy polymeric materials with oleic acid. Prospective materials, (4), 33-37.

8. Mostovoy, A.S. (2015). Prescription modification of epoxy resin using new high-performance plasticizers. Modern High Technologies, (7), 66-70.

9. Marakhovsky, K. M., Osipchik, V. S., Vodovozov, G. A., \& Papina, S. N. (2016). Modification of an epoxy binder with enhanced characteristics for the production of composite materials. Advances in Chemistry and Chemical Technology, 30(10), 56-58.

10. Krutko, E. T., \& Prolopchuk, N. R. (2017). Melaminealkide and exopy resins chemical modification. Polimernye materialy i technologii, 3(1), 47-59.

11. Epoxy compound Etal-Inject $T$ (n.d.). Retrieved from http://www.epital.ru/yacht1/inject.html.

12. GOST 4647-2015 Plastics. Charpy Impact Test Method (n.d.). Retrieved from http://internet-law.ru/gosts/gost/62398/ (date of treatment 01/15/19).

\section{Дослідження впливу пластифікаторів і термопластів на міцність та ударну в'язкість епоксидних смол}

\section{Л. М. Мустафа ${ }^{1,2}$, М. Б. Ісмаілов ${ }^{1,2}$, А. Ф. Санін ${ }^{3}$}

1 - АТ «Національний центр космічних досліджень і технологій», м. Алмати, Республіка Казахстан

2 - Satbayev University, м. Алмати, Республіка Казахстан, e-mail: mustafa laura@mail.ru

3 - Дніпровський національний університет імені Олеся Гончара, м. Дніпро, Україна, e-mail: afedsa60@gmail.com

Мета. Підвищення ударної в'язкості й міцності епоксидних смол «гарячого» та «холодного» отвердження 3 використанням модифікуючих пластифікаторів і термопластичних полімерів.

Методика. Досліджували епоксидні смоли холодного й гарячого отверждження ЕД-20 і Етал Інжект-Т, модифіковані пластифікаторами трьох видів і термопластичними полімерами чотирьох видів. Визначали ударну в'язкість методом Шарпі й міцність на стиск немодифікованих і модифікованих смол за різного вмісту модифікаторів.
Результати. Із досліджених пластифікаторів найбільш виражений вплив на міцність і ударну в'язкість обох типів смол надає трікрезилфосфат. Краще сполучення міцності та ударної в'язкості смоли ЕД-20 досягається при вмісті трикрезилфосфат $5 \%$, при більш високому вмісті різко знижується міцність матеріалу. Для смоли Етал Інжект-Т високі значення даних характеристик отримані при вмісті $15 \%$ трікрезілфосфату, при введенні меншої кількості модіфікатору міцність матеріалу практично не змінюється. Модифікування термопластичними полімерами чинить менший вплив на властивості епоксидних смол, ніж модифікування пластифікаторами. Найбільш ефективними добавками до ЕД-20 є високотемпературні полікарбонат (5\%) і полісульфон (10 та $15 \%)$, уведення яких призводить до одночасного підвищення обох характеристик. Для Етал Інжект-Т помітне збільшення ударної в'язкості відбувається при введенні 5-15\% полікарбонату, але міцність смоли майже не змінюється. Комплексне модифікування смол сумішшю пластифікатора й термопласта призводить до зниження як ударної в'язкості, так і міцності на стиск для обох типів смол.

Наукова новизна. При затвердінні полімерної суміші молекули пластифікатора, дисперговані в середовище макромолекул епоксидної смоли, послаблюють жорстке просторове зшивання макромолекул, роблять їх більш рухливими. У результаті підвищується ударна в'язкість i, у деяких випадках, міцність унаслідок спрямованої переорієнтації макромолекул при деформації. Зміна механічних властивостей епоксидної смоли при модифікуванні термопластами визначається міцністю адгезійного зв'язку смоли й дисперсних частинок термопласта, а також ступенем гетерофазності утвореної суміші.

Практична значимість. Результати змін механічних властивостей епоксидної смоли при модифікуванні пластифікаторами й термопластами можуть бути використані при виготовленні удароміцних композиційних матеріалів конструкційного призначення, у тому числі авіаційної та ракетно-космічної техніки.

Ключові слова: епоксидна смола, модифікатори, пластифікатори, термопласти, термообробка, ударна в'язкість

\section{Исследование влияния пластификаторов и термопластов на прочность и ударную вязкость эпоксидных смол}

\section{Л. М. Мустафа ${ }^{1,2}$, М. Б. Исмаилов ${ }^{1,2}$, А. Ф. Санин ${ }^{3}$}

1 - АО «Национальный центр космических исследований и технологий», г. Алматы, Республика Казахстан 2 - Satbayev University, г. Алматы, Республика Казахстан, e-mail: mustafa_laura@mail.ru

3 - Днепровский национальный университет имени Олеся Гончара, г. Днепр, Украина, e-mail: afedsa60@gmail.com

Цель. Повышение ударной вязкости и прочности эпоксидных смол «горячего» и «холодного» отверждения с использованием модифицированных пластификаторов и термопластичных полимеров.

Методика. Исследовали эпоксидные смолы холодного ЭД-20 и горячего Этал Инжект-Т отверждения, модифицированные пластификаторами трех видов и термопластичными полимерами четырех видов. Определяли ударную вязкость методом Шарпи и прочность на сжатие немодифицированных и модифицированных смол при различном содержании модификаторов.

Результаты. Из исследованных пластификаторов наиболее выраженное влияние на прочность и ударную вязкость обоих типов смол оказывает трикрезилфосфат. Лучшее сочетание прочности и ударной вязкости смолы 
ЭД-20 достигается при содержании трикрезилфосфата $5 \%$, при более высоком содержании резко падает прочность материала. Для смолы Этал Инжект-Т высокие значения данных характеристик получены при содержании $15 \%$ трикрезилфосфата, при введении меньшего количества модификатора прочность материала практически не изменяется. Модифицирование термопластичными полимерами оказывает менее выраженное влияние на свойства эпоксидных смол, чем модифицирование пластификаторами. Наиболее эффективными добавками в ЭД-20 являются высокотемпературные поликарбонат (5\%) и полисульфон (10 и $15 \%)$, введение которых приводит к одновременному повышению обеих характеристик. Для Этал Инжект-Т заметное увеличение ударной вязкости происходит при введении 5-15\% поликарбоната, но прочность смолы почти не изменяется. Комплексное модифицирование смол смесью пластификатора и термопласта приводит к снижению как ударной вязкости, так и прочности на сжатие для обоих типов смол.

Научная новизна. При отверждении полимерной смеси молекулы пластификатора, диспергированные в среду макромолекул эпоксидной смолы, ослабляют жесткую пространственную сшивку макромолекул, делают их более подвижными. В результате возрастает ударная вязкость и, в некоторых случаях, прочность вследствие направленной переориентации макромолекул при деформации. Изменение механических свойств эпоксидной смолы при модифицировании термопластами определяется прочностью адгезионной связи смолы и дисперсных частиц термопласта, а также степенью гетерофазности образованной смеси.

Практическая значимость. Результаты изменения механических свойств эпоксидной смолы при модифицировании пластификаторами и термопластами могут быть использованы для получения ударопрочных композиционных материалов конструкционного назначения, в том числе авиационной и ракетно-космической техники.

Ключевые слова: эпоксидная смола, модификаторы, пластификаторы, термопласты, термообработка, ударная вязкость

Recommended for publication by Ye.A. Dzhour, Doctor of Technical Sciences. The manuscript was submitted 09.01.20. 